\title{
A Comparison of the Primary and Secondary Wood Products Sectors in Louisiana
}

\section{Usporedba primarnoga i sekundarnog sektora drvnih proizvoda u državi Louisiani}

\author{
Original scientific paper • Izvorni znanstveni rad \\ Received-prispjelo: 24. 2. 2011. \\ Accepted-prihvaćeno: 14. 7. 2011. \\ UDK: $630 * 79 ; 630 * 83$ \\ doi:10.5552/drind.2011.1107
}

\begin{abstract}
As part of an ongoing research program, the Louisiana forest products industry is surveyed every five years to identify salient issues, challenges, and opportunities. In this paper, we compare the results from two studies conducted on the primary and secondary sectors in Louisiana. In the past, we produced two papers based on research results, one for the primary and one for the secondary sector. However, this paper compares the answers to questions asked in both surveys. Louisiana's forests represent an important resource for the state, both in terms of income to landowners and as inputs to the forest products industry. Both primary and secondary respondents indicate an interest in increasing their workforce in the next five years. The issues that drive the company expansion fall into four areas: the overall attractiveness of the business climate of the community and state, labor productivity, costs and supply, and financing. The results of this study can be used by Louisiana industry members in the primary and secondary sectors to identify common challenges, opportunities and issues that promote or hinder sector development. Policymakers can work more efficiently with industry members where commonalities exist. Understanding the markets, plant location decisions, raw material availability, workforce training needs, and other issues can be a source of competitive advantage for Louisiana manufacturers.
\end{abstract}

Keywords: wood products, Louisiana, United States, primary products, secondary products

SAŽETAK • Industrija šumskih proizvoda u Louisiani prati se u sklopu tekućega istraživačkog programa i u njoj se svakih pet godina provodi anketa da bi se ustanovili aktualni problemi, izazovi i mogućnosti. U radu se uspoređuju rezultati dvaju uzastopnih istraživanja primarnoga i sekundarnog sektora drvnih proizvoda u Louisiani. Do sada su već napisana dva članka o rezultatima tih istraživanja, jedan o primarnom sektoru i jedan o sekundarnome. U ovom radu uspoređuju se odgovori na zajednička pitanja iz oba istraživanja. Šume u Louisiani važan su državni resurs u smislu prihoda zemljoposjednika i u smislu ulazne sirovine za industriju drvnih proizvoda. Ispitanici $i$ u primarnome $i$ sekundarnom sektoru pokazuju zanimanje za povećanje broja zaposlenih $u$ sljedećih pet godina. Činitelji koji pokreću povećanje poduzeća pripadaju jednoj od četiri skupine: sveobuhvatnoj privlačnosti poslovne klime u društvu i državi, produktivnosti rada, troškovima i nabavi, financiranju. Rezultatima ove studije mogu se koristiti članovi primarnoga i sekundarnog sektora drvnih proizvoda u Louisiani da bi usta-

\footnotetext{
${ }^{1}$ Author is director and professor at Louisiana Forest Products Development Center, School of Renewable Natural Resources, Louisiana State University Agricultural Center, Baton Rouge, Louisiana.

' Autor je direktor i profesor u Centru za razvoj šumskih proizvoda, Školi za obnovljive prirodne resurse Poljoprivrednog centra Sveučilišta u Louisiani, Baton Rouge, Louisiana.
} 
novili izazove, mogućnosti i probleme koji promoviraju ili sprječavaju razvoj sektora. Političke se odluke mogu donositi mnogo učinkovitije u suradnji s predstavnicima struke ako postoje zajednički interesi. Poznavanje tržišta, odluke o lokaciji tvornica, dostupnost sirovina, obučavanje radne snage i druga pitanja mogu biti izvor kompetetivnih prednosti prozvođača u Lousiani.

Ključne riječi: drvni proizvodi, Louisiana, Sjedinjene Države, primarni proizvodi, sekundarni proizvodi

\section{INTRODUCTION}

\section{UVOD}

"Lumber industry hit hard" was the caption in The Baton Rouge Advocate, daily newspaper (Calder 2008). It was referring to the housing slump that saw the lowest number of new housing starts since 1959 (US Census Bureau 2008). Housing is a major driving force of wood markets where 70 percent of wood building materials, primarily softwood lumber and structural panels, are used in residential construction including both new construction and remodeling (UNECE/FAO 2008). With such a downturn in the housing industry, production and prices of wood building materials have collapsed. According to Random Lengths (2009), overall softwood production was down 27 percent in 2008 compared to 2005, and prices for framing lumber were down 38 percent from their 2004 peak. Panel production suffered similar market turns, dropping 25 percent from 2005 and composite structural panel prices plunged 37 percent from 2004 (Random Lengths 2009). As of early 2009, prices have been even weaker and many mills are curtailing production and/or downsizing (IBIS World 2009, Wood Digest 2008).

In August 2005, two Category 5 hurricanes hit the Gulf Coast of the United States. Hurricane Katrina made landfall with a direct hit to New Orleans causing catastrophic levee failure and widespread flooding. One month later, Hurricane Rita hit the West Louisiana/East Texas border. Combined, they damaged over 4.4 billion board feet of standing timber and wiped out the equivalent of more than two years' worth of pine sawtimber harvest and more than 11 years' worth of hardwood sawtimber harvest for the entire state (Chang, 2006). The closest timber loss Louisiana faced, up to then, was the southern pine beetle outbreaks of 1985 86 , with a loss of 1.1 billion board feet (Mistretta and Bylin, 1987). In this paper, we present a brief history of the forest sector in Louisiana and then discuss the results of a study which offers a perspective on the state of the forest products industry in Louisiana three years after the hurricanes hit the state.

\subsection{Louisiana's forest products industry}

\subsection{Industrija šumskih proizvoda u Louisiani}

The development of the lumber industry in Louisiana began in the period following the Civil War. There was a great demand for lumber to rebuild the wartorn areas of the South as well as to supply the industrial revolution taking place in the North (Maxwell, 1973; Quarterman and Keever, 1962; Foster, 1912). Longleaf yellow pine was abundant throughout the state. The chief demand for lumber was for construction, telegraph poles, railroad ties, and furniture manufacturing
(Maxwell, 1973). In addition to pine, Louisiana sawmills also cut oak, ash, gum, and cypress as well as many other woods. The milling of cypress had significant economic importance to the southeastern region of the state, where it was used principally for manufacturing of shingles and cisterns (Kellogg, 1909).

Forests cover 13.5 million acres or 48 percent of Louisiana with pine accounting for 52 percent and hardwoods for 48 percent (LFA 2008). Forests and forestry are an important part of Louisiana's history, culture and economy. Although Louisiana forests are almost evenly divided between pine and hardwoods, approximately six times more softwood is harvested annually than hardwood (LDAF 2007). In 2006, the output of softwood roundwood products totaled 712 million cubic feet, while the output of hardwood roundwood products was 175 million cubic feet (SRS 2007).

Over the past decade, forestry has been Louisiana's number one agricultural crop, generating \$3.3 billion in farm gate value and value-added revenue in 2008 (LSU AgCenter 2009). However, 2008 marked two consecutive years of significant reductions in the forest products sector of Louisiana's economy, which coincides with the sharp contraction in the national economy that began toward the end of 2007. Pine sawtimber harvest decreased by 30 percent, to a total statewide harvest of 833.2 million board feet. The hardwood sawtimber harvest fell to 137.7 million board feet (a 21 percent decrease) in 2008 (LSU AgCenter 2009).

The Louisiana wood products manufacturing sector is comprised of an estimated 75 primary manufacturers and 545 secondary manufacturers (furniture, cabinet, millwork) (Louisiana Forest Products Development Center 2009). Primary products are those produced directly from raw timber input. Examples include chips, lumber, veneer, plywood and their by-products. Secondary products use primary products as input for remanufacturing. Examples include various types of panels, engineered composites or dimension stock. Secondary products can also include final consumer products such as furniture (Hughes and Vlosky, 2000). The forest sector, including forestry and forest products, is Louisiana's second largest employer with approximately 17,000 manufacturing jobs and 8,000 jobs in the harvesting/ transportation of timber (LFA, 2008).

In an effort to provide information to Louisiana forest industry members, policymakers and other stakeholders, the Louisiana Forest Products Development Center (LFPDC) has periodically conducted primary and secondary wood products industry surveys for the past 15 years to identify salient issues, challenges, and opportunities. Vlosky, Chance, and Harding (1994) conducted an industry survey, which showed 
that the secondary wood products industry in Louisiana was fragmented and consisted of many small businesses, with 75 percent having 10 employees or less. At that time secondary industry companies were relying primarily on word-of-mouth to promote products directly to customers, thereby limiting the distribution of their sales.

Vlosky (1995) reported on the primary sector in Louisiana. He found that in 1993, nearly half of respondent companies had sales of at least \$10 million. The majority of respondents were strictly softwood producers (45.5 percent), while 30.0 percent were using only hardwoods and 24.5 percent used both softwood and hardwood raw materials. In contrast to secondary manufacturers, 47 percent of sales were made out-of-state and 12 percent of sales went to export markets. Primary respondents also used word-of-mouth as the main vehicle to promote and sell their products. The factors that were considered to be the greatest impediments to company expansion were workman's compensation, proximity to raw materials, taxes, availability of capital, labor training issues and community industrial climate.

One of the recurring themes in these studies is the need for a trained and qualified workforce in the forest products industry. In each study, industry respondents indicated that they would have liked to add employees; however the lack of adequately trained labor was a limiting factor in doing so. In order to better understand the specific training needs in Louisiana, Vlosky and Chance (2001) conducted a study of the secondary sector. The overall conclusion was that appropriate training of the workforce must become a priority for Louisiana's value-added industry to be competitive in the marketplace. The most desired knowledge was concerning safety regulations and in dealing with customers, followed by quality and process control and basic problem-solving skills.

In this paper, we compare the results of two studies conducted on the primary and secondary sectors in Louisiana. In the past, we produced two papers based on research results, one for the primary and one for the secondary sector. However, this paper, based on the 2009 study, compares the results of the questions common to both surveys.

\section{MATERIAL AND METHODS} 2. MATERIJAL I METODE

Using a directory of Louisiana wood products industries compiled by the Louisiana Forest Products Development Center (2009), 75 primary solid wood products companies and 545 secondary or value-added companies were surveyed. The study was conducted using mailed surveys. Survey development and implementation generally followed methods and procedures recommended by Dillman and described as the Tailored Design Method (TDM) (Dillman, 2000). Accordingly, the survey process included a pre-notification postcard, first survey mailing, a reminder postcard, second mailing and, because response rates were not what we ex- pected, after two mailings, a third mailing. After accounting for undeliverable surveys and unusable returned surveys, the adjusted response rates were 42 percent and 10 percent for primary and secondary companies, respectively. The response rate for the primary sector is quite good but, unfortunately, the response rate for the secondary sector is lower than we have experienced in past years. Although Jones and Lang (1980) point out that increasing the response rate does not necessarily improve the precision of survey results, we feel the secondary sector results can be considered as being exploratory (Adams, 1986; Hochstim, 1967).

Walonick (1993) believes that most researchers view non-response bias as a continuum, ranging from fast responders to slow responders (with non-responders defining the end of the continuum). Research has shown that late respondents typically respond similarly to non-respondents. Accordingly, second mailing respondents, as a proxy for non-respondents, were compared to first mailing respondents to test for non-response bias (Donald, 1960). Out of the 60 comparable variables, differences were detected at $\alpha=0.05$ for three variables (5 percent).

\section{RESULTS AND DISCUSSION} 3. REZULTATI I RASPRAVA

Figure 1 indicates that primary industry was located at higher concentration in the forested areas of Louisiana in the Northeast, Central and Southeast parts of the state and secondary industry was more prevalent in urban areas of Baton Rouge, New Orleans and Lafayette in Southern Louisiana. Seventy-six percent of primary respondents are headquartered in Louisiana with the balance having headquarters in Pennsylvania, South Carolina, Tennessee, Texas and Washington. All secondary manufacturers are headquartered in Louisiana. Louisiana is divided into parishes, known in the other 49 states as counties.

Figure 2 shows the percent of respondents manufacturing primary products. Multiple responses were possible as some companies are diversified and produce more than one product. Hardwood lumber is the highest ranked product with 66 percent of respondents followed by softwood lumber (48 percent). Past studies of Louisiana production had these products reversed. The economic downturn and subsequent soft demand for softwood lumber for construction is the likely reason for this reversal in order. Respondents in the secondary industry manufacture a wide range of value-added products (Figure 3 ). In this case as well, multiple responses were possible. Cabinets were mainly produced in 2008 with 71 percent of respondents, followed by molding and millwork (55 percent).

Figure 4 shows where respondents obtained their wood raw materials in 2008. Sixty-eight percent and 69 percent of primary and secondary producer respondents sourced raw materials from Louisiana, respectively. Often there can be concerns from forest sector industry members and stakeholders that "too much" raw materials are imported from other states to manu- 
Vlosky: A Comparison of the Primary and Secondary Wood Products Sectors in Louisiana....

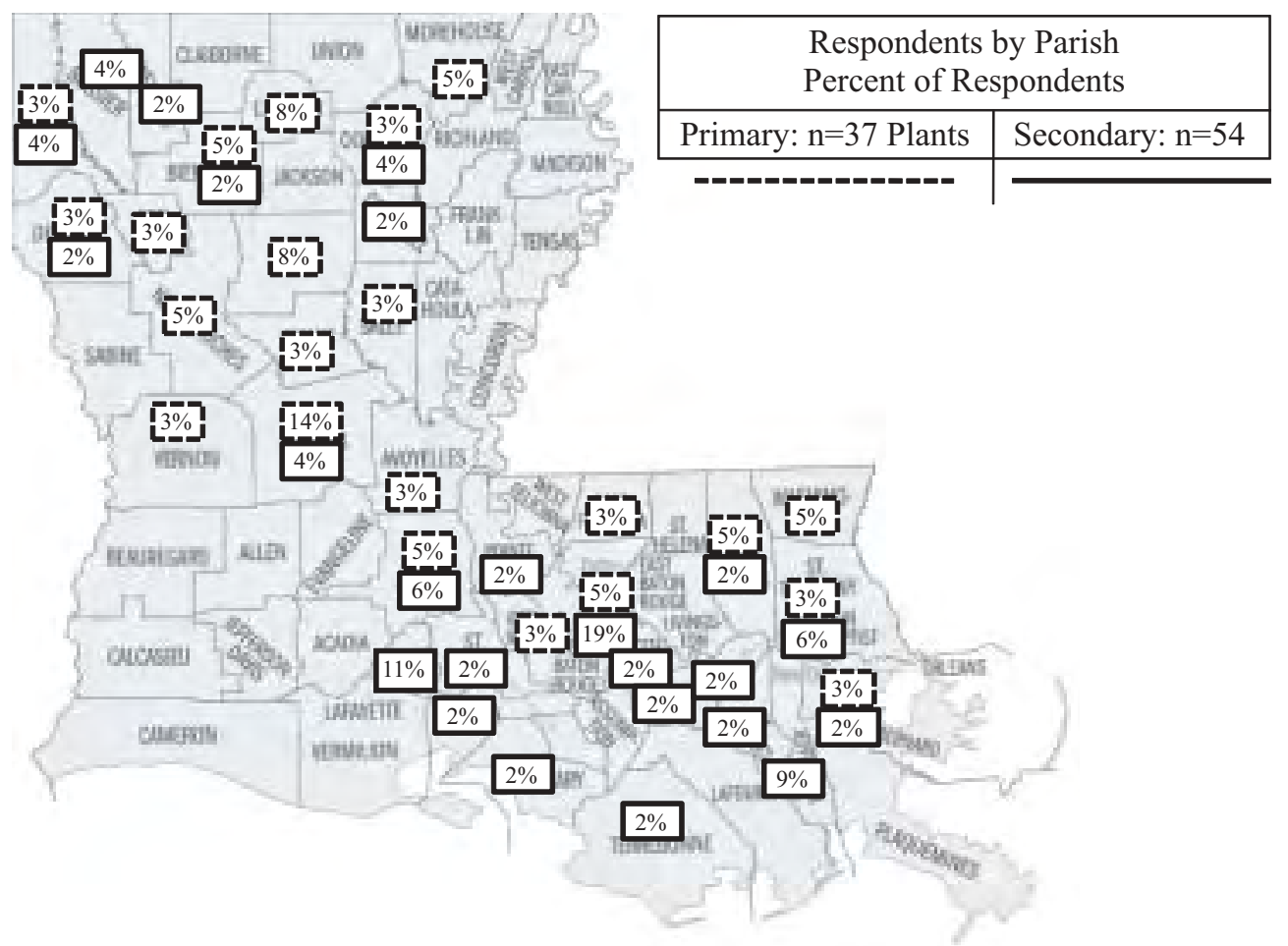

Figure 1 Respondent location by parish (percent of respondents) (Primary: $n=37$; Secondary: $\mathrm{n}=54$ )

Slika 1. Lokacija ispitanika prema okruzima (postotak ispitanika) (primarni sektor $n=37$, sekundarni sektor $n=54$ )

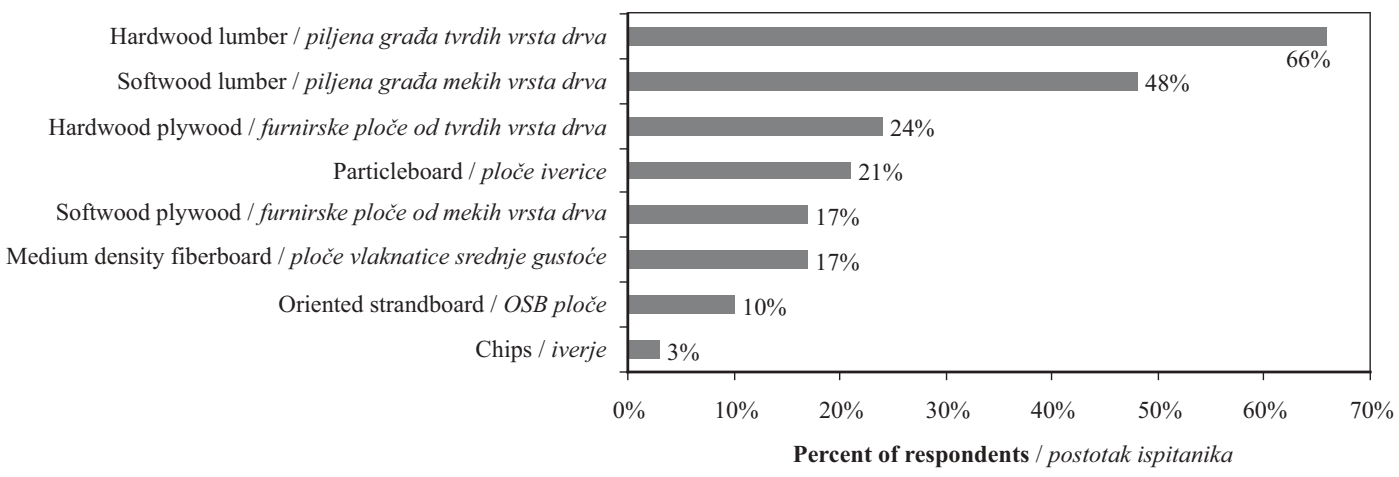

Figure 2 Products manufactured by primary producers (percent of respondents) (multiple responses possible, $n=53$ )

Slika 2. Proizvodi primarnih proizvođača (postotak ispitanika) (mogući višestruki odgovori, $n=53$ )

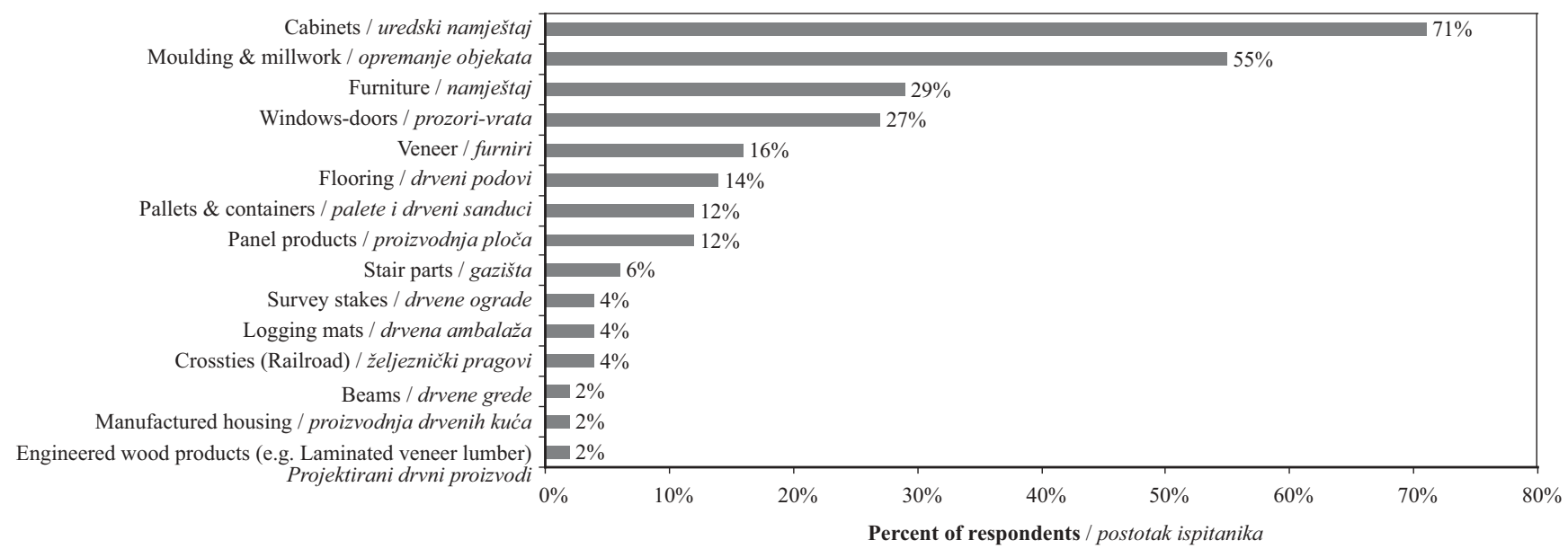

Figure 3 Products manufactured by secondary producers (percent of respondents) (multiple responses possible, $n=53$ )

Slika 3. Proizvodi sekundarnih proizvođača (postotak ispitanika) (mogući višestruki odgovori, $n=53$ ) 


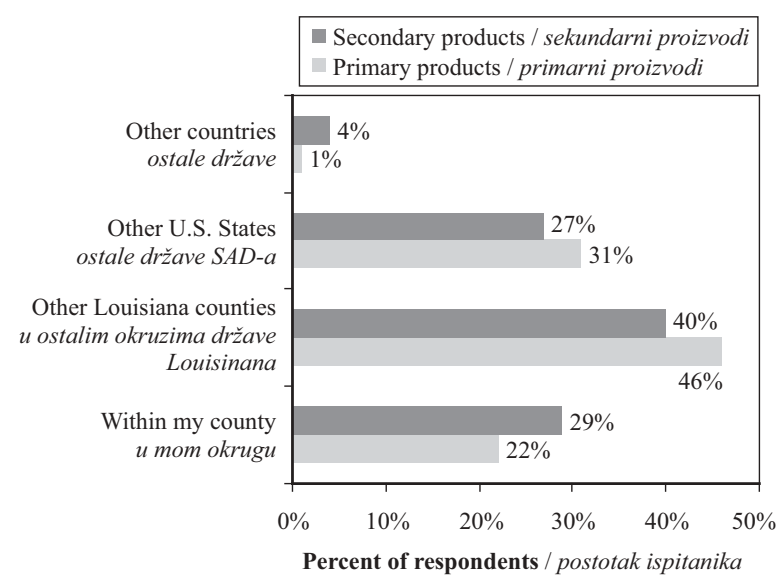

Figure 4 Where respondents obtain wood raw materials (percent of respondents) (Primary: $n=29$; Secondary: $n=51$ ) Slika 4. Gdje ispitanici nabavljaju drvnu sirovinu (postotak ispitanika) (primarni sektor $n=29$, sekundarni sektor $n=51$ )

facture wood products, thereby forgoing adding as much value as possible from in-state raw materials.

Figure 5 compares primary and secondary respondent company size in terms of number of full-time employees. The number of respondents for primary industry respondents was fairly evenly distributed among the employee categories while 87 percent of secondary industry respondents had 19 or fewer employees. A Chi-Square test was performed to compare these frequencies and they were found to be significantly diffe$\operatorname{rent}\left(\chi^{2}=33.37\right.$, asymptotic 2 -sided significance $\left.=0.000\right)$. With regard to part-time employees, both primary and secondary respondents are skewed strongly to having 1-9 employees in this category (Figure 6). Secondary respondents had 100 percent of their part-time employees in this category. A Chi-Square test indicated a

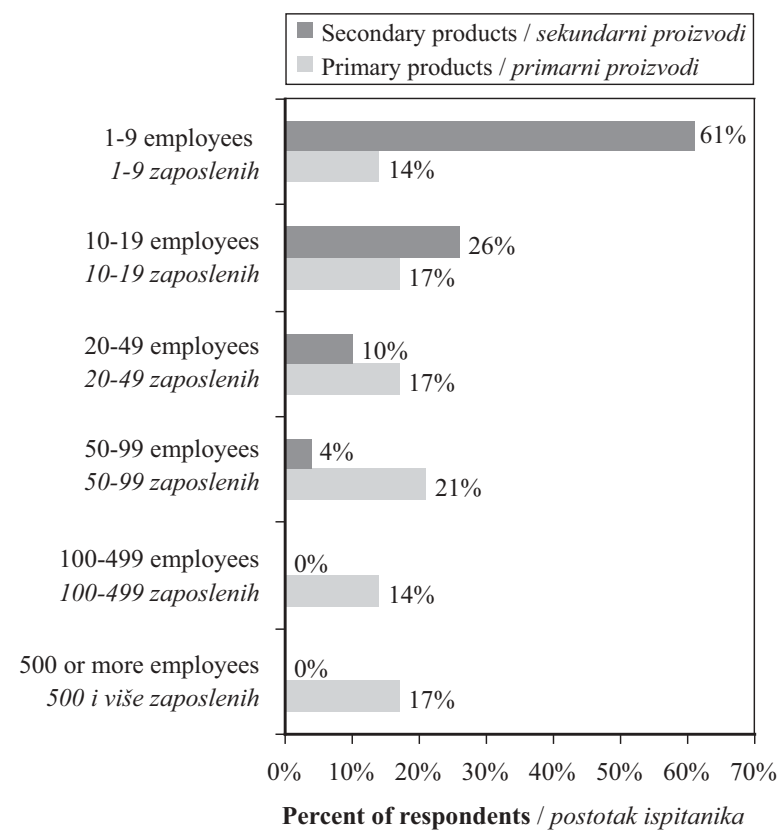

Figure 5 Respondent company size by number of full-time employees (Primary: $n=29$; Secondary: $n=51$ )

Slika 5. Veličina poduzeća ispitanika izražena brojem zaposlenika s punim radnim vremenom (primarni sektor $n=29$, sekundarni sektor $n=51$ )

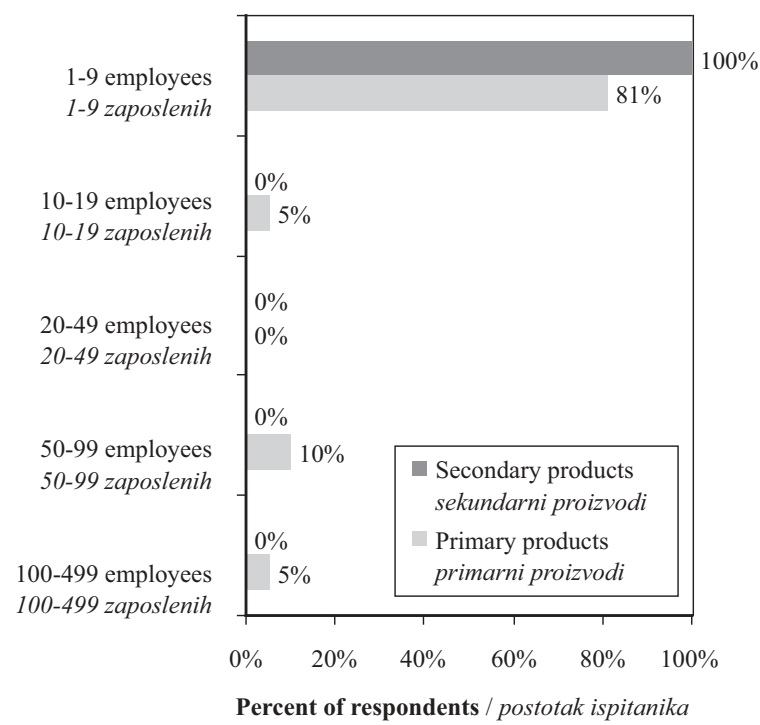

Figure 6 Respondent company size by number of part-time employees (Primary: $n=21$; Secondary: $n=24$ )

Slika 6. Veličina poduzeća ispitanika izražena brojem zaposlenika sa skraćenim radnim vremenom (primarni sektor $n=21$, sekundarni sektor $n=24$ )

lack of a significant difference in the part-time employee frequencies $\left(\chi^{2}=5.02\right.$, asymptotic 2-sided significance $=0.171$ ).

Figure 7 indicates plans by respondents to increase workforce in 2009 and 2010-2014. For both time periods, secondary industry respondents were planning on hiring more employees ( 38 percent and 49 percent) than in primary industry ( 33 percent and 38 percent). This too is likely due to the economic downturn that has negatively impacted housing starts.

There are many reasons for respondents not planning to add to their work force (Table 1). The primary sector respondents' main reason was the lack of markets for their company's products (28 percent of respondents), followed by lack of adequate labor (21 percent), workmen's compensation costs (17 percent) and state taxes (17 percent). Secondary industry respondents shared some concerns. Their main reasons were workmen's compensation costs (28 percent), lack of adequate labor (26 percent), cost of training employees (20 percent), wages (18 percent) and health costs (18 percent).

Using Likert-type scales anchored on levels of importance, respondents evaluated different methods of promoting their products (Scale: 1=very unimportant; $3=$ neither unimportant nor important; $5=$ =ery important) (Table 2). The results were compared to determine significant differences from the neutral midpoint using one sample t-tests and sorted by t-statistic values. The shaded portion of the table indicates non-significant results (at $\alpha=0.05$ ). For primary respondents, radio ads, direct mailing and newspaper ads were significantly lower than the midpoint while distributor support, word of mouth, and sales reps were significantly higher than the midpoint. For secondary respondents, manufacturers, all except one promotion method, word of mouth, had a negative t-value and all except using the 


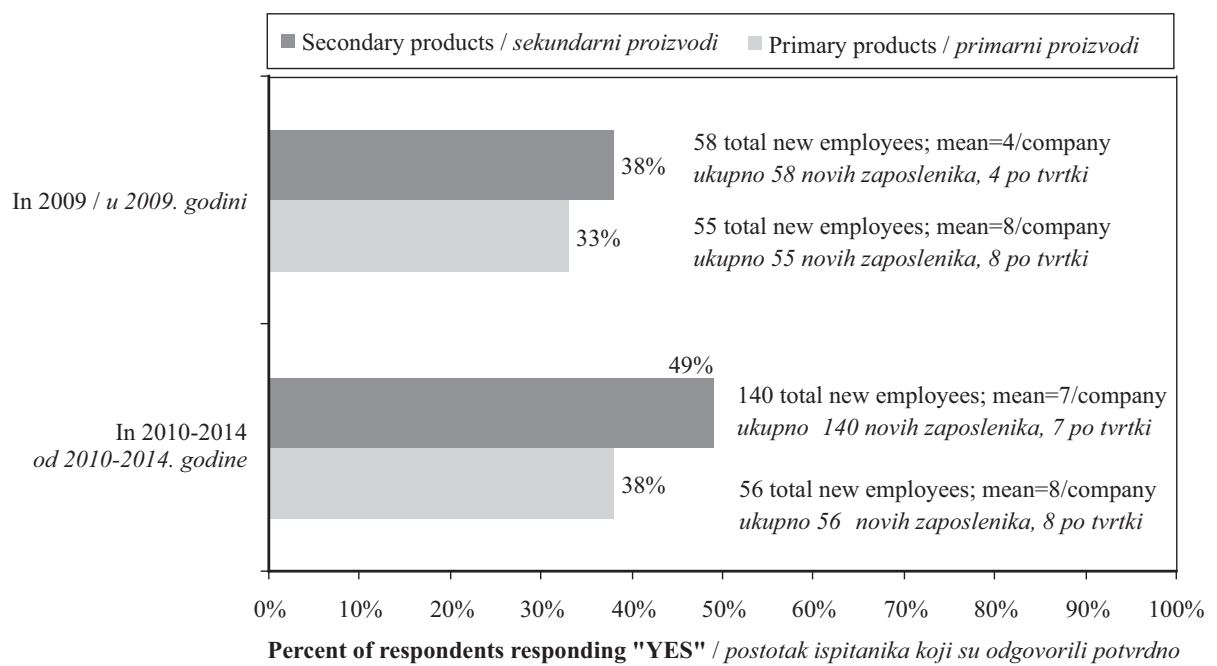

Figure 7 Plans to increase workforce in $2009 \&$ 2010-2014 (Primary: $n=27$; Secondary: $n=48$ )

Slika 7. Planovi za povećanje broja zaposlenih u 2009. i u razdoblju $2010-2014$. (primarni sektor $n=27$, sekundarni sektor $n=48$ )

World Wide Web (a carryover term from previous studies) were significantly different from the neutral point.

What factors make wood products companies successful? Again, using the same scale of importance and comparisons to the 3.0 neutral midpoint, respondents were asked to rate factors that contribute to their company's success (Table 3). For primary industry respondents, all but two factors were statistically significant with regard to positive differences from the neutral midpoint (at $\alpha=0.05$ ). One was negatively non-significant (Internet presence) and the other was positively non-significant (computer capabilities). Factors identified as having the highest contribution to company success were "Product availability" and "Long-term customer relationships" (both 4.8/5.0). For secondary manufacturers, in addition to "Internet pre- sence" and "Computer capabilities", "Marketing skil1s" was also not significantly different from the midpoint. Means for all the three of these non-significant factors were above the midpoint. Factors with the highest means were "Our product quality", "Long-term customer relationships", and "Company reputation" (all 4.9/5.0).

Challenges that companies face in achieving or maintaining success are on the other end of the spectrum (Table 4). Three statistically significant factors (different from midpoint at $\alpha=0.05$ ) were common to both primary and secondary respondents. These were "Volatile pricing", "Getting quality raw material", and "Getting consistent raw material". One additional factor was statistically significant for secondary industry respondents, "Finding ways to promote my company's products".

Table 1 Reasons for not having plans to hire new employees (multiple responses possible) (Primary: n=18; Secondary: $n=30$ ) Tablica 1. Razlozi nepovećanja broja zaposlenih u idućem razdoblju (mogući višestruki odgovori, primarni sektor $n=27$, sekundarni sektor $n=48$ )

\begin{tabular}{|l|c|c|l|}
\hline & $\begin{array}{l}\text { Primary } \\
\text { Primarni }\end{array}$ & $\begin{array}{l}\text { Secondary } \\
\text { Sekundarni }\end{array}$ & \\
\hline $\begin{array}{l}\text { Lack of markets for my company's products } \\
\text { Nedostatak tř̌išta za proizvode poduzeća }\end{array}$ & $28 \%$ & $28 \%$ & $\begin{array}{l}\text { Workmen's compensation costs } \\
\text { Troškovi plaća radnika }\end{array}$ \\
\hline $\begin{array}{l}\text { Can't find adequate labor } \\
\text { Nemogućnost pronalaska adekvatne radne snage }\end{array}$ & $21 \%$ & $26 \%$ & $\begin{array}{l}\text { Can’t find adequate labor } \\
\text { Nemogućnost pronalaska adekvatne radne snage }\end{array}$ \\
\hline $\begin{array}{l}\text { Workmen's compensation costs } \\
\text { Troškovi plaća radnika }\end{array}$ & $17 \%$ & $20 \%$ & $\begin{array}{l}\text { Can’t afford to train employees } \\
\text { Nemogućnost obučavanja zaposlenika }\end{array}$ \\
\hline $\begin{array}{l}\text { State taxes } \\
\text { Državni porezi }\end{array}$ & $17 \%$ & $18 \%$ & $\begin{array}{l}\text { Labor health costs are too high } \\
\text { Previsoki troškovi zdravstvenog osiguranja }\end{array}$ \\
\hline $\begin{array}{l}\text { I do not want to grow the company } \\
\text { Ne želim rast poduzé́a }\end{array}$ & $14 \%$ & $18 \%$ & $\begin{array}{l}\text { Wages required to hire new employees } \\
\text { Troškovi zapošljavanja novih zaposlenika }\end{array}$ \\
\hline $\begin{array}{l}\text { Labor health costs are too high } \\
\text { Previsoki troškovi zdravstvenog osiguranja }\end{array}$ & $14 \%$ & $14 \%$ & $\begin{array}{l}\text { I do not want to grow the company } \\
\text { Ne želim rast poduzeća }\end{array}$ \\
\hline Local taxes / Lokalni porezi & $3 \%$ & $10 \%$ & $\begin{array}{l}\text { State taxes / Državni porezi } \\
\text { Local taxes } \\
\text { Can't afford to train employees } \\
\text { Nemogućnost obučavanja zaposlenika }\end{array}$ \\
\hline $\begin{array}{l}\text { Wages required to hire new employees } \\
\text { Troškovi zapošljavanja novih zaposlenika }\end{array}$ & $0 \%$ & $4 \%$ & $\begin{array}{l}\text { Lack of markets for my company's products } \\
\text { Nedostatak tržišta za proizvode poduzéca }\end{array}$ \\
\hline
\end{tabular}


Table 2 Methods of promoting company products (One-Sample Statistics Compared to 3.0) (Neutral Point) (Scale: 1=very unimportant; $3=$ neither unimportant nor important; $5=$ =ery important)

Tablica 2. Metode promidžbe proizvoda poduzeća (statistička usporedba jednog uzorka s neutralnom točkom 3,0) $(1-$ potpuno nevažno; 3 - ni nevažno ni važno; 5 - vrlo važno)

\begin{tabular}{|c|c|c|c|c|c|c|c|}
\hline \multicolumn{8}{|l|}{$\begin{array}{l}\text { Primary industry respondents } \\
\text { Ispitanici primarne industrije }\end{array}$} \\
\hline & $N$ & $\begin{array}{c}\text { Mean } \\
\text { Srednja } \\
\text { vrijednost }\end{array}$ & $\begin{array}{c}\text { Std. } \\
\text { Deviation } \\
\text { Standardna } \\
\text { devijacija } \\
\end{array}$ & \begin{tabular}{|} 
Std. Error Mean \\
Standardna \\
pogreška
\end{tabular} & $t$ & $d f$ & Sig. (2-tailed) \\
\hline Radio ads / Radijski oglas & 24 & 1.8 & 1.179 & 0.241 & -5.022 & 23 & 0.000 \\
\hline Direct mailing / Izravno pismo & 24 & 2.0 & 1.083 & 0.221 & -4.337 & 23 & 0.000 \\
\hline Newspaper ads / Oglas u novinama & 25 & 2.1 & 1.320 & 0.264 & -3.484 & 24 & 0.002 \\
\hline World wide web / Internetske stranice & 24 & 2.7 & 1.239 & 0.253 & -1.318 & 23 & 0.201 \\
\hline $\begin{array}{l}\text { Trade magazine ads } \\
\text { Oglas u poslovnim novinama }\end{array}$ & 26 & 2.7 & 1.468 & 0.288 & -1.202 & 25 & 0.241 \\
\hline Catalogs / Katalozi & 25 & 2.7 & 1.345 & 0.269 & -1.189 & 24 & 0.246 \\
\hline Magazine ads / Oglas u časopisu & 26 & 2.7 & 1.373 & 0.269 & -1.000 & 25 & 0.327 \\
\hline Trade shows / Sajmovi & 26 & 3.2 & 1.415 & 0.277 & 0.693 & 25 & 0.495 \\
\hline Distributor support / Potpora distributera & 27 & 3.7 & 1.347 & 0.259 & 2.857 & 26 & 0.008 \\
\hline Word of mouth / Usmenim putem & 29 & 3.9 & 1.407 & 0.261 & 3.299 & 28 & 0.003 \\
\hline Sales reps / Trgovački predstavnik & 28 & 4.0 & 1.170 & 0.221 & 4.684 & 27 & 0.000 \\
\hline \multicolumn{8}{|l|}{$\begin{array}{l}\text { Secondary industry respondents } \\
\text { Ispitanici sekundarne industrije }\end{array}$} \\
\hline Radio ads / Radijski oglas & 39 & 1.5 & 0.790 & 0.126 & -11.559 & 38 & 0.000 \\
\hline Direct mailing / Izravno pismo & 39 & 1.7 & 0.977 & 0.157 & -8.355 & 38 & 0.000 \\
\hline Catalogs / Katalozi & 39 & 2.0 & 1.112 & 0.178 & -5.761 & 38 & 0.000 \\
\hline $\begin{array}{l}\text { Trade magazine ads } \\
\text { Oglas u poslovnim novinama }\end{array}$ & 41 & 1.9 & 1.300 & 0.203 & -5.406 & 40 & 0.000 \\
\hline Newspaper ads / Oglas u novinama & 41 & 2.0 & 1.204 & 0.188 & -5.318 & 40 & 0.000 \\
\hline Magazine ads / Oglas u časopisu & 40 & 2.0 & 1.300 & 0.206 & -5.109 & 39 & 0.000 \\
\hline Trade shows / Sajmovi & 39 & 2.1 & 1.244 & 0.199 & -4.635 & 38 & 0.000 \\
\hline Distributor support / Potpora distributera & 40 & 2.4 & 1.372 & 0.217 & -2.882 & 39 & 0.006 \\
\hline Sales reps / Trgovački predstavnik & 40 & 2.5 & 1.536 & 0.243 & -2.162 & 39 & 0.037 \\
\hline World wide web / Internetske stranice & 40 & 2.9 & 1.598 & 0.253 & -0.396 & 39 & 0.694 \\
\hline Word of mouth / Usmenim putem & 50 & 4.8 & 0.815 & 0.115 & 15.436 & 49 & 0.000 \\
\hline
\end{tabular}

The final question common to both sectors asked respondents to rate different infrastructure-related factors that influence their decisions to either expand capacity at existing facilities or build new production facilities. A Likert-type scale anchored on levels of agreement was used (Scale: 1=strongly disagree; $3=$ neither disagree nor agree; $5=$ strongly agree). A discussion with the director of forestry, agriculture and food sectors with the Louisiana State Department of Economic Development (Short, 2009) led to the decision to combine primary and secondary respondents to conduct a factor analysis for these influences. The rationale was to tease out the major constructs that influence the wood products industry as a whole. Understanding these dimensions is a potentially useful tool from a policy and planning perspective.

Table 5 shows the results of the Factor Analysis. Principal component factor analysis, with varimax rotation was conducted to identify these underlying dimensions. Several preliminary factor analysis solutions were examined before the final factor analysis solution was found. The 12 infrastructure-related influences posed were reduced to 10 . The sample size $(n=71)$ for the 10 variables exceeds the minimum required number of 5 observations per variable required for factor analysis (Hair et al. 1998). The Kaiser-Meyer-Olkin overall Measure of Sampling Adequacy (0.689), Bartlett test of nonzero correlations (0.000), Measures of Sampling Adequacy (range from 0.573 to 0.852 ) on the anti-image correlation matrix, and small partial correlations all indicate that the data set is suitable for Factor Analysis.

The latent root criterion (eigenvalue $\geq 1$ ) was used in extracting the factors. Orthogonal varimax rotation was used to disperse the factor loadings within the factors to achieve a more interpretable solution (Field 2000). The four factors explain 77.8 percent of the total variance of the 10 variables as follows: Factor 1 (24.5\%); Factor 2 (21.8\%); Factor 3 (17.6\%); Factor 4 $(13.9 \%)$. The cut-off point for interpretation of the loadings was \pm 0.50 .

- Factor 1 has three significantly high loadings (0.697-0.899), which are related to taxes and ove- 
Table 3 Attributes contributing to company success (One-Sample Statistics Compared to 3.0 (Neutral Point) (Scale: 1=very unimportant; $3=$ =neither unimportant nor important; $5=$ =very important)

Tablica 3. Svojstva koja pridonose uspjehu poduzeća (statistička usporedba jednog uzorka s neutralnom točkom 3,0$)(1$ potpuno nevažno; 3 - ni nevažno ni važno; 5 - vrlo važno)

\begin{tabular}{|c|c|c|c|c|c|c|c|}
\hline \multicolumn{8}{|l|}{$\begin{array}{l}\text { Primary industry respondents } \\
\text { Ispitanici primarne industrije }\end{array}$} \\
\hline & $N$ & $\begin{array}{c}\text { Mean } \\
\text { Srednja } \\
\text { vrijed- } \\
\text { nost }\end{array}$ & $\begin{array}{c}\text { Std. Devia- } \\
\text { tion } \\
\text { Standardna } \\
\text { devijacija }\end{array}$ & $\begin{array}{l}\text { Std. Error } \\
\text { Mean } \\
\text { Standardna } \\
\text { pogreška }\end{array}$ & $t$ & $d f$ & $\begin{array}{c}\text { Sig. } \\
(2- \\
\text { tailed) }\end{array}$ \\
\hline Internet presence / Postojanje interneta & 28 & 2.8 & 1.101 & 0.208 & -1.030 & 27 & 0.312 \\
\hline Computer capabilities / Mogućnosti računala & 28 & 3.4 & 1.166 & 0.220 & 1.784 & 27 & 0.086 \\
\hline $\begin{array}{l}\text { Distribution capabilities } \\
\text { Mogućnosti distribucije }\end{array}$ & 28 & 3.9 & 1.145 & 0.216 & 3.959 & 27 & 0.000 \\
\hline Marketing skills / Marketinške vještine & 27 & 3.9 & 0.907 & 0.175 & 4.878 & 26 & 0.000 \\
\hline Access to markets / Pristup tržištu & 27 & 4.1 & 0.864 & 0.166 & 6.905 & 26 & 0.000 \\
\hline Flexible delivery / Fleksibilnost isporuke & 27 & 4.2 & 0.801 & 0.154 & 7.932 & 26 & 0.000 \\
\hline Fair prices / Poštene cijene & 29 & 4.3 & 0.857 & 0.159 & 8.453 & 28 & 0.000 \\
\hline $\begin{array}{l}\text { Fast response to inquiries } \\
\text { Brz odgovor na potraživanja }\end{array}$ & 28 & 4.4 & 0.737 & 0.139 & 9.996 & 27 & 0.000 \\
\hline Company reputation / Reputacija poduzeća & 29 & 4.7 & 0.850 & 0.158 & 10.711 & 28 & 0.000 \\
\hline $\begin{array}{l}\text { Knowledgeable sales people } \\
\text { Sposobnost ljudi u prodaji }\end{array}$ & 28 & 4.5 & 0.637 & 0.120 & 12.752 & 27 & 0.000 \\
\hline Our product quality / Kvaliteta proizvoda & 29 & 4.7 & 0.702 & 0.130 & 13.229 & 28 & 0.000 \\
\hline $\begin{array}{l}\text { High level of overall customer service } \\
\text { Visoka razina usluga potrošačima }\end{array}$ & 28 & 4.6 & 0.567 & 0.107 & 15.000 & 27 & 0.000 \\
\hline Product availability / Dostupnost proizvoda & 28 & 4.8 & 0.518 & 0.098 & 17.870 & 27 & 0.000 \\
\hline $\begin{array}{l}\text { Long-term customer relationships } \\
\text { Trajni odnosi s kupcima }\end{array}$ & 28 & 4.8 & 0.476 & 0.090 & 20.265 & 27 & 0.000 \\
\hline \multicolumn{8}{|l|}{$\begin{array}{l}\text { Secondary industry respondents } \\
\text { Ispitanici sekundarne industrije }\end{array}$} \\
\hline Internet presence / Postojanje interneta & 41 & 3.3 & 1.342 & 0.210 & 1.280 & 40 & 0.208 \\
\hline $\begin{array}{l}\text { Computer capabilities } \\
\text { Mogućnosti računala }\end{array}$ & 42 & 3.4 & 1.322 & 0.204 & 1.751 & 41 & 0.087 \\
\hline Marketing skills / Marketinške vještine & 40 & 3.4 & 1.357 & 0.214 & 1.981 & 39 & 0.055 \\
\hline $\begin{array}{l}\text { Distribution capabilities } \\
\text { Mogućnosti distribucije }\end{array}$ & 41 & 3.7 & 1.309 & 0.204 & 3.461 & 40 & 0.001 \\
\hline Access to markets / Pristup tržištu & 41 & 3.7 & 1.175 & 0.183 & 3.589 & 40 & 0.001 \\
\hline $\begin{array}{l}\text { Knowledgeable sales people } \\
\text { Sposobnost ljudi u prodaji }\end{array}$ & 42 & 4.1 & 1.435 & 0.221 & 5.055 & 41 & 0.000 \\
\hline Flexible delivery / Fleksibilnost isporuke & 44 & 3.9 & 1.117 & 0.168 & 5.399 & 43 & 0.000 \\
\hline $\begin{array}{l}\text { Fast response to inquiries } \\
\text { Brz odgovor na potraživanja }\end{array}$ & 44 & 4.1 & 1.268 & 0.191 & 5.943 & 43 & 0.000 \\
\hline $\begin{array}{l}\text { High level of overall customer service } \\
\text { Visoka razina usluga potrošačima }\end{array}$ & 46 & 4.5 & 1.110 & 0.164 & 9.295 & 45 & 0.000 \\
\hline Product availability / Dostupnost proizvoda & 44 & 4.5 & 0.901 & 0.136 & 10.708 & 43 & 0.000 \\
\hline Fair prices / Poštene cijene & 50 & 4.6 & 0.697 & 0.099 & 16.443 & 49 & 0.000 \\
\hline $\begin{array}{l}\text { Long-term customer relationships } \\
\text { Trajni odnosi s kupcima }\end{array}$ & 47 & 4.9 & 0.612 & 0.089 & 20.971 & 46 & 0.000 \\
\hline Our product quality / Kvaliteta proizvoda & 51 & 4.9 & 0.575 & 0.080 & 23.637 & 50 & 0.000 \\
\hline Company reputation / Reputacija poduzeća & 50 & 4.9 & 0.566 & 0.080 & 24.000 & 49 & 0.000 \\
\hline
\end{tabular}

rall industrial climate, thus the factor was named "Taxes/Business Climate".

- Factor 2 also has three significantly high loadings (0.638-0.866) on variables associated with labor productivity and costs. Accordingly, the factor was named "Labor Productivity and Costs".

- Factor 3 has two items with significantly high loadings (0.839-0.898) on bank financing and availa- bility of working capital and was named "Financing”.

- Factor 4 has two significant loadings (0.745-0.842) that are the availability of unskilled and skilled labor. This factor was named "Labor Supply". 
Table 4 Factors in company challenges to success One-Sample Statistics Compared to 3.0 (Neutral Point) (Scale: 1=very unimportant; $3=$ neither unimportant nor important; $5=$ very important)

Tablica 4. Činitelji u poduzeću koji onemogućuju uspjeh (statistička usporedba jednog uzorka s neutralnom točkom 3,0$)(1$ potpuno nevažno; 3 - ni nevažno ni važno; 5 - vrlo važno)

\begin{tabular}{|c|c|c|c|c|c|c|c|}
\hline \multicolumn{8}{|l|}{ Primary industry respondents / Ispitanici primarne industrije } \\
\hline & $N$ & $\begin{array}{c}\text { Mean } \\
\text { Srednja } \\
\text { vrijed- } \\
\text { nost }\end{array}$ & $\begin{array}{c}\text { Std. } \\
\text { Deviation } \\
\text { Standardna } \\
\text { devijacija }\end{array}$ & $\begin{array}{l}\text { Std. Error } \\
\text { Mean } \\
\text { Standardna } \\
\text { pogreška }\end{array}$ & $t$ & $d f$ & $\begin{array}{c}\text { Sig. } \\
(2- \\
\text { tailed) }\end{array}$ \\
\hline $\begin{array}{l}\text { Lack of adequate machinery } \\
\text { Nedostatak potrebnih strojeva }\end{array}$ & 26 & 2.6 & 1.206 & 0.236 & -1.789 & 25 & 0.086 \\
\hline $\begin{array}{l}\text { Inefficient processing capabilities } \\
\text { Neučinkoviti proizvodni procesi }\end{array}$ & 26 & 2.7 & 1.129 & 0.221 & -1.563 & 25 & 0.131 \\
\hline $\begin{array}{l}\text { Competition from producers in my state } \\
\text { Konkurentni proizvođači } u \text { državi }\end{array}$ & 26 & 2.8 & 1.405 & 0.276 & -0.558 & 25 & 0.582 \\
\hline Delivery problems / Problemi isporuke & 27 & 2.9 & 1.121 & 0.216 & -0.515 & 26 & 0.611 \\
\hline Not having enough capacity / nedovoljni kapaciteti & 28 & 3.0 & 0.943 & 0.178 & 0.000 & 27 & 1.000 \\
\hline $\begin{array}{l}\text { Competition from producers in my region } \\
\text { Konkurentni proizvođači u regiji }\end{array}$ & 27 & 3.3 & 1.209 & 0.233 & 1.433 & 26 & 0.164 \\
\hline $\begin{array}{l}\text { Finding ways to promote my company's products } \\
\text { Nepostojanje dobre promidžbe proizvoda }\end{array}$ & 28 & 3.4 & 1.129 & 0.213 & 1.674 & 27 & 0.106 \\
\hline Volatile pricing / Nepostojane cijene & 25 & 4.2 & 0.866 & 0.173 & 6.928 & 24 & 0.000 \\
\hline Getting quality raw material / Dobava kvalitetne sirovine & 28 & 4.3 & 0.897 & 0.169 & 7.586 & 27 & 0.000 \\
\hline Getting consistent raw material / Dosljedna dobava sirovine & 29 & 4.4 & 0.825 & 0.153 & 9.234 & 28 & 0.000 \\
\hline \multicolumn{8}{|c|}{ Secondary industry respondents / Ispitanici sekundarne industrije } \\
\hline Delivery problems / Problemi isporuke & 40 & 2.7 & 0.987 & 0.156 & -1.763 & 39 & 0.086 \\
\hline Lack of adequate machinery / Nedostatak potrebnih strojeva & 42 & 2.8 & 1.353 & 0.209 & -1.026 & 41 & 0.311 \\
\hline $\begin{array}{l}\text { Inefficient processing capabilities } \\
\text { Neučinkoviti proizvodni procesi }\end{array}$ & 40 & 2.9 & 1.228 & 0.194 & -0.386 & 39 & 0.701 \\
\hline $\begin{array}{l}\text { Competition from producers in my region } \\
\text { Konkurentni proizvođači u regiji }\end{array}$ & 41 & 3.2 & 1.283 & 0.200 & 0.852 & 40 & 0.399 \\
\hline $\begin{array}{l}\text { Competition from producers in my state } \\
\text { Konkurentni proizvođači u državi }\end{array}$ & 42 & 3.2 & 1.284 & 0.198 & 1.202 & 41 & 0.236 \\
\hline Not having enough capacity / Nedovoljni kapaciteti & 40 & 3.3 & 1.137 & 0.180 & 1.669 & 39 & 0.103 \\
\hline $\begin{array}{l}\text { Finding ways to promote my company's products } \\
\text { Nepostojanje dobre promidžbe proizvoda }\end{array}$ & 41 & 3.5 & 1.247 & 0.195 & 2.380 & 40 & 0.022 \\
\hline Volatile pricing / Nepostojane cijene & 44 & 4.1 & 1.108 & 0.167 & 6.395 & 43 & 0.000 \\
\hline Getting quality raw material / Dobava kvalitetne sirovine & 47 & 4.4 & 0.919 & 0.134 & 10.158 & 46 & 0.000 \\
\hline Getting consistent raw material / Dosljedna dobava sirovine & 46 & 4.4 & 0.906 & 0.134 & 10.413 & 45 & 0.000 \\
\hline
\end{tabular}

Table 5 Factor analysis of influences on company decision to expand current capacity or build new facilities (Primary and Secondary respondents combined) $(n=71)$

Tablica 5. Analiza činitelja koji utječu na odluku poduzeća da poveća postojeće kapacitete ili izgradi nove objekte (kombinirani odgovori ispitanika primarnoga i sekundarnog sektora, $n=71$ )

\begin{tabular}{|l|c|c|c|c|}
\hline & \multicolumn{4}{|c|}{ Factor / Činitelj } \\
\hline & $\begin{array}{c}\text { Business } \\
\text { climate } \\
\text { Poslovna klima }\end{array}$ & $\begin{array}{c}\text { Labor productivity } \\
\text { \& costs / Produktiv- } \\
\text { nost i troškovi }\end{array}$ & $\begin{array}{c}\text { Financing } \\
\text { Financiranje }\end{array}$ & $\begin{array}{c}\text { Labor supply } \\
\text { Ponuda radne } \\
\text { snage }\end{array}$ \\
\hline State taxes / Državni porezi & $\mathbf{0 . 8 9 9}$ & 0.284 & 0.053 & 0.102 \\
\hline Local taxes / Lokalni porezi & $\mathbf{0 . 8 9 3}$ & 0.163 & 0.012 & 0.138 \\
\hline $\begin{array}{l}\text { Community industrial climate } \\
\text { Društvena industrijska klima }\end{array}$ & $\mathbf{0 . 6 9 7}$ & 0.063 & 0.314 & -0.128 \\
\hline Productivity of labor / Produktivnost rada & 0.073 & $\mathbf{0 . 8 6 6}$ & 0.041 & 0.197 \\
\hline Labor costs / Radni troškovi & 0.283 & $\mathbf{0 . 8 5 4}$ & 0.181 & 0.016 \\
\hline Workman's compensation / Plaće radnika & 0.470 & $\mathbf{0 . 6 3 8}$ & 0.293 & 0.110 \\
\hline Available capital / Raspoloživi kapital & 0.128 & 0.169 & $\mathbf{0 . 8 9 8}$ & 0.053 \\
\hline Bank financing / Bankovno financiranje & 0.119 & 0.103 & $\mathbf{0 . 8 3 9}$ & 0.171 \\
\hline $\begin{array}{l}\text { Unskilled labor supply } \\
\text { Ponuda neobučene radne snage }\end{array}$ & 0.124 & -0.036 & 0.150 & $\mathbf{0 . 8 4 2}$ \\
\hline Skilled labor supply / Ponuda obučene radne snage & -0.046 & 0.381 & 0.055 & $\mathbf{0 . 7 4 5}$ \\
\hline
\end{tabular}

Extraction Method: Principal Component Analysis. Rotation Method: Varimax with Kaiser Normalization 


\section{CONCLUSION}

\section{ZAKLJUČAK}

In the aftermath of Hurricanes Katrina and Rita in 2005 , combined with the national recession and associated severe decline in housing starts that began in 2008, the Louisiana wood products sector seems to be hanging on. In fact, even though this study was conducted early in 2009, when these market conditions were apparent, over a third of respondents from both the primary and secondary sectors said that they had plans to increase employment levels in 2009 and in the 2010-2014 period. For those respondents not planning to hire new employees, labor-related issues were most cited such as the lack of an available labor pool, lack of ability to train new employees, and onerous workmen's compensation costs.

With regard to factors that promote or hinder company success, long-term relationships with customers, general reputation in the market place, products quality and availability were most important success factors for both respondent groups. Information technology competencies such as simply having computing capabilities or an Internet presence were deemed to be the least important factors for company success. These data infer that the wood products industry, at least in Louisiana, remains a "people business" where personal contact counts. With regard to business challenges, neither group identified a plethora of factors that hinder success. The consistent challenges for all respondents had to do with volatile pricing which generally has to do with market and economic conditions, and raw material issues, particularly the ability to procure a consistent source of supply for quality inputs.

Finally, when we looked at the issues that drive company expansion, respondent data were segmented nicely into four areas: the overall attractiveness of the business climate of the community and state, labor productivity, costs and supply, and financing. Overall business and community climate relate to a number of issues including quality of life for employees and their families, tax structures and other typically state-level infrastructure issues. Labor issues in the Louisiana wood products have been researched frequently over the past 16 years and have been consistently identified as constraints to industry growth and competitiveness. Lack of training options targeting the unique skill sets of the primary and secondary industry has been a particularly serious problem over this period. Financing and availability of capital are issues facing any industrial sector regardless of location. These are also important influences on respondent company growth or expansion. Many companies would like to grow but cannot due to these infrastructure, labor and financing constraints.

In summary, Louisiana has an established wood products industry and a significant forest land base. The forest sector provides significant contributions to the economies of most of parishes in Louisiana and is a major employer statewide. The results in this article help to provide the much needed continuity of the understanding of the wood products industry in the state.

\section{REFERENCES}

\section{LITERATURA}

1. Adams, J.S., 1986: An experiment on question and response bias. Public Opinion Quarterly 1986; 20: 593597, http://dx.doi.org/10.1086/266658

2. Calder, C., 2008: Lumber industry hit hard .Louisiana loggers struggle while mills slow production, close because of sluggish housing market. Baton Rouge Advocate. Section F, Page 1. November 16, 2008.

3. Chang, S.J., 2006: The Hurricane Impact on Southern Pine Sawtimber Stumpage Prices in Louisiana. Louisiana Agriculture. Spring 2006. pp. 26-27.

4. Dillman, D.A., 2000: Mail and Internet Surveys - The Tailored Design Method, Second Edition. John Wiley \& Sons, New York.

5. Donald, M.N., 1960: Implications of non-response for the interpretation of Mail Questionnaire Data. Public Opinion Quarterly, 24:99-114, http://dx.doi.org/10.1086/266934

6. Field, A., 2000: Discovering Statistics Using SPSS for Windows. SAGE Publications Ltd. ISBN 0761957545. 496p.

7. Foster, J.H., 1912: Forest conditions in Louisiana. Bull. 114. U.S. Department of Agriculture, Forest Service. 39 pp.

8. Hair, J.; Anderson, R.; Tatham, R.; Black, W., 1998: Multivariate data analysis. 5th edition. Prentice-Hall, Inc. ISBN 0138948585.730 p.

9. Hochstim, J.R., 1967: A critical comparison of three strategies of collecting data from households. Journal of the Statistical Association 62(9):967-989.

10. Hughes, D. W.; Vlosky, R.P., 2000: Economic Implications of Forest Products Sector Industry Development in Northwest Louisiana. Research Bulletin \#874. LSU AgCenter. Baton Rouge. 31 pp.

11. IBIS World. 2009: Sawmills \& Wood Production in the US: 32111. 43 pp. http://www.ibisworld.com/reports/ reportdownload.aspx . $\mathrm{cid}=1 \& \mathrm{rtid}=1 \& \mathrm{e}=383 \& \mathrm{ft}=$ pdf. (Accessed 16 Feb 09.)

12. Kellogg, R.S., 1909: The Timber Supply of the United States. USDA FS, Circular 166. 24 pp.

13. Jones, W., and J. Lang. 1980: "Sample composition bias and response bias in a mail survey: A comparison of inducement methods." Journal of Marketing Research 17:69-76, http://dx.doi.org/10.2307/3151119

14. LDAF (Louisiana Department of Agriculture and Forestry). 2007. Annual Harvest Summary. www.ldaf.state. la.us/portal/Portals/0/FOR/Reports/LaTimberAndPulpwoodProduction/Annualharvest percent20Summary/ ANNUAL percent20HARVEST percent20SUMMARY. pdf. (Accessed 11 March 09.)

15. LFA (Louisiana Forestry Association). 2008: Louisiana Forestry Quiz. www.laforestry.com. (Accessed 16 Feb 09.)

16. Louisiana Forest Products Development Center. 2009: Louisiana Forest Industries Website. www.lsuagcenter. com/forestindustries. (Accessed January 4, 2009)

17. LSU AgCenter. 2009: Louisiana Summary - Agriculture \& Natural Resources 2008. Louisiana State University Agricultural Center. Baton Rouge, LA. Page 16.

18. Maxwell, R.S., 1973: The Impact of Forestry on the Gulf South. Forest History 17(1):30-35

19. Mistretta, P.A.; Bylin, C.V., 1987: Incidence and Impact of Damage to Louisiana's Timber, 1985. USDA FS SRS, Resource Bulletin SO-117. 22 pp.

20. Quarterman, E.; Keever, C. 1962: Southern mixed hardwood forest: Climax in the Southeastern Coastal Plain, 
U.S.A. Ecological Monographs 32(2):167-185, http://dx.doi.org/10.2307/1942384

21. Random Lengths. 2009: Prices and production available in Random Lengths Yearbook 2007, Eugene, Oregon. www. randomlengths.com. (Accessed February 16, 2009).

22. Short, K., 2009: Louisiana Department of Economic Development. Personal Communication. April 29.

23. SRS (Southern Research Station, USDA FS). 2007: Timber Product Output (TPO) Reports. srsfia2.fs.fed.us/php/ tpo2/tpo2.php. (Accessed March 11, 2009).

24. UNECE/FAO. 2008. Forest Products Annual Market Review, 2007-2008. Geneva Timber and Forest Study Paper 23, ECE/TIM/SP/23. Pp. 33-44. www.unece.org/timber/ docs/fpama/2008/fpamr2008.htm. (Accessed March 18, 2009).

25. US Census Bureau. 2008: Housing starts. http://www. census.gov/const/www/newresconstindex.html. (Accessed February 16, 2009).

26. Vlosky, R.P.; Chance, N.P., 2001: Employment structure and training needs in the Louisiana value-added wood products industry. Forest Prod. J. 51(3):34-41.

27. Vlosky, R.P., 1995: An Overview of the Louisiana Primary Solid Wood Products Industry. Working Paper \#2. Louisiana Forest Products Laboratory. Louisiana State University. Baton Rouge, LA. 18 pp.
28. Vlosky, R.P.; Chance, N.P.; Harding, O.V., 1994: An Overview of the Louisiana Secondary Wood Products Industry. Working Paper \#1. Louisiana Forest Products Laboratory. Louisiana State University. Baton Rouge, LA. $33 \mathrm{pp}$.

29. Walonick, D., 1993: Everything You Wanted to Know about Questionairres but Were Afraid to Ask. http://www. statpac.com/research-papers/questionnaires.htm (Accessed April 28, 2009).

30. Wood Digest. 2008. Editorial: The storm before the calm. 1p. http://www.wooddigest.com/print/Wood-Digest/Thestorm-before-the-calm/2\$1444. (Accessed February 15, 2009).

\section{Corresponding address:}

Prof. RICHARD VLOSKY, Ph.D.

Director and Professor

Louisiana Forest Products Development Center

School of Renewable Natural Resources

Louisiana State University Agricultural Center

Baton Rouge, LA 70803, USA

e-mail: rvlosky@agcenter.lsu.edu 